\title{
Developing Sexual Rights: Challenges and Trends in Latin America
}

\section{Roger Raupp Rios}

\section{Introduction}

The current situation concerning the rights of lesbian, gay and transgender persons in Latin America can be examined from various perspectives. These might include analyses of the successes and failures, the limits and possibilities, and the formal recognition of these rights by Latin American national states, in an approach pertaining more to political science. Studies can also be proposed on the effectiveness of existing rights, based on the degree of commitment by various government institutions involved in their enforcement, adopting a more sociological perspective. Anthropological research can also point to the impacts that formal recognition of these rights can have on the social representations concerning these groups, both inside and outside the groups themselves.

In this article, I propose to examine the current situation regarding the rights of lesbian, gay, bisexual and transgender (LGBT) people from a legal perspective. What does such an analysis entail? What is the relevance of a legal approach to this issue? One should begin by distinguishing between a legal analysis and a mere inventory of legislation and case law on the topic. A legal analysis involves more than compiling data; on the contrary, it requires a critical examination of the prevailing legislation and its potential and limits for dealing with these rights, whether or not the legislation is explicit in relation to sexual rights. A legal analysis should also cover the trends and challenges for the recognition and enforcement of these rights, serving as important material for a more adequate understanding of reality, to be incorporated by researchers and activists. To the extent that the law (whether in its official wording or its enforcement by legal bodies) is also a fact of social reality, we must both understand and analyse it in order to adequately reflect on and practice it. Hence, the relevance of a legal approach.

This article thus begins with a typology of legal frameworks as to the level of repression against (or legal protection of) LGBT people. This initial exercise will be followed by listing the trends and challenges in the Latin American scenario, aimed at an understanding of the current situation and prospects concerning these rights. I conclude with observations on what might be done to further advance efforts to overcome discrimination on the basis of sexual orientation.

\section{The legal situation of LGBT people in Latin America}

There are many ways of thinking about the legal situation of LGBT people in Latin America. Two perspectives predominate, the 'descriptive' and the 'operational'. The 'descriptive perspective' demands a compilation and systematic review of the legislation enacted around the region. This compilation, although unquestionably important, is beyond the objectives of the current article, which aims primarily to analyse the law's effectiveness in relation to the sexual orientation discrimination reality rather than to describe the legislative and administrative sources for Latin American guidelines on the issue. Taking an 'operational perspective' involves systematising and discussing the most effective legal arguments and procedural strategies for the best possible legal protection required by LGBT people. Based on consecrated hermeneutic canons in legal theory, this perspective requires a broader legal and political comprehension of the role of the sexual orientation discrimination law in the region. Such understanding enables legal professionals, researchers and activists to extract the greatest possible efficacy vis-à-vis the 
reality of the discrimination, while also pursuing the most adequate procedural strategies.

\section{Typology of legal frameworks concerning the rights of LGBT people}

The relationship between sexuality and the law, viewed as a legal framework (that is, the set of normative state instruments prevailing at a given moment in a given country, encompassing both legislative acts and court decisions), is an ancient one. Traditionally, state law was produced as an instrument to reinforce and preserve the majority and dominant sexual moral norms. State law has served to confirm hegemonic sexual relations and practices. Examples include the consecration of the petit bourgeois nuclear family, the attribution of sexual rights and duties between spouses, and the criminalisation of homosexual acts.

\section{With the emergence of social movements} vindicating the acceptance of practices and relations divorced from this model, the issue of sexual rights, and especially that of LGBT rights, was shifted into the political arena and thus into the legal debate. The emergence of these demands and the recognition of some rights (although slowly and unevenly) launched a new modality in the relationship between these legal frameworks and sexuality (Heinze 1995). Historically, and concentrating on modernity, one observes the emergence of these rights in the 1980s, when a landmark decision by the European Court of Human Rights overruled a law criminalising sodomy, on the grounds that said legislation violated a basic human right, namely the right to privacy.

Since then it has been possible to speak of various levels of protection for LGBT sexual rights, and hence the following proposed typology of legal frameworks:

1 Legal frameworks with a minimal degree of protection: those that have revoked the traditional prohibition of sexual practices that depart from hegemonic standards (especially linked to penal law).

2 Legal frameworks with an intermediate level of protection: those which besides not criminalising such sexual practices also institute measures to penalise discriminatory acts, especially by prohibiting discrimination on the grounds of sexual orientation.

3 Legal frameworks with a maximum degree of protection: those which besides not criminalising the above-mentioned practices and penalising discriminatory acts also establish positive measures for the protection and recognition of the sexual practices and identities of gays, lesbians and transgender persons.

In the Latin American context, the application of this typology of legal frameworks vis-à-vis the degree of protection of LGBT rights allows one to evaluate the situation with such rights in the region. The objective of this article is not to map the situation in each individual country (a task that would require a joint effort by numerous researchers and detailed data collection, not to mention keeping pace with the dynamism characterising the legislative and juridical output in such a broad area). Rather, the article seeks to identify the most salient elements in this scenario, allowing an analysis of the trends and challenges for these rights in Latin America.

An overview of the Latin American situation, considering the available data, shows that: (1) there is no legal framework in Latin America that criminalises homosexual sexual practices, except in specific contexts such as military establishments; (2) the majority of legal frameworks in Latin America penalise acts of discrimination on the grounds of expressions of sexuality (e.g. Argentina, Brazil, Colombia, Ecuador, Mexico and Peru); and (3) few legal frameworks establish positive measures for the protection and recognition of these sexual rights (Argentina and Brazil). Only Cuban law explicitly establishes punishment for public manifestations of homosexuality (Penal Code, Article 303). In some other countries, legislation that criminalises relations between persons of the same sex has only very recently been revoked: in Chile, for example, homosexuality was criminalised until $1998 .{ }^{1}$

Meanwhile, in the sphere of protective frameworks, Brazil, Argentina and Colombia are examples of countries which not only prohibit discrimination, but also institutionally recognise unions between persons of the same sex (in Brazil and Colombia, based on court rulings, while in Argentina there is explicit legislation) (Golin et al. 2003; Cabal et al. 2001). The degree of protection varies from country to country. Brazil has shown a high degree of institutional protection, at least formally, since the country launched the 2nd National Human Rights Programme and the 'Brazil without Homophobia' Government Plan, and of course the government 
support (especially through the Ministry of Health) for visibility campaigns and specific attention to gay and lesbian groups.

In the context of protective frameworks, Ecuador should be highlighted for its Constitutional provision explicitly prohibiting discrimination on grounds of sexual orientation (Leon 1999), with the following wording:

All persons shall be considered equal [before the law] and shall enjoy the same rights, freedoms, and opportunities, without discrimination on grounds of birth, age, sex, ethnicity, color, social origin, language, religion, political affiliation, economic position, sexual orientation, health status, disability, or difference of any other nature.

A broader survey of the situation with LGBT rights in Latin America also shows in practice the absence of legal regulation based on a human rights perspective in dealing with the specific situation of transsexualism or that of travestis (transvestites). ${ }^{2}$ On these fronts, the biomedical approach usually prevails, especially in relation to transsexualism. As for the treatment of travestis, even in countries where cross-dressing is not considered illegal, a repressive approach prevails in respect of their engagement in street prostitution and other forms of sex work, based on the criminalisation of what are considered obscene acts in public byways and repression of prostitution. Having briefly indicated these elements, we can proceed to an inventory of trends and challenges for LGBT rights in Latin America.

\section{Trends in the development of LGBT rights}

Several trends can be extracted from the emergence and development of LGBT rights in Latin America. In the light of the above overview, the following points will be emphasised: (1) recognition of these rights within an overall context of re-democratisation in Latin America; (2) the impact of the HIV/AIDS epidemic; (3) the link between these rights and public health concerns; and (4) the affirmation of these rights within demands for social rights.

Since the mid-1980s, Latin America has undergone a process of re-democratisation resulting from the exhaustion of various military dictatorships and changes related to the international order and stemming from the dismantling of the former Soviet Union and the subsequent détente in East-West relations. Within this broader context, there emerged spaces for the strengthening of civil society and various social movements, among which the feminist and gay movements have played outstanding roles in demanding LGBT rights vis-à-vis the state.

More specifically, this dynamic reached the legislative and judiciary branches, not only by the gradual establishment of alliances and dialogue with progressive Congressional forces, but also by the strengthening of judicial bodies. The latter, encouraged by post-Second World War Continental European Constitutionalism, were opened to the possibility of human rights protection, consecrated not only in the international order but also in the respective national Constitutions. The latter was an important factor for the development of LGBT rights in Latin America. Constitutional courts in various countries such as Brazil, Colombia and Peru handed down rulings that penalised acts of discrimination on the grounds of sexual orientation (Cabal et al. 2001).

Another important factor in the development of LGBT sexual rights has been their increased impetus since the emergence of the HIV/AIDS epidemic. Although the epidemic was initially a factor in the stigmatisation of gays and travestis, eventually the responses developed to fight the epidemic provided greater reflection and networking among such groups (Cáceres et al. 2002). This in turn helped raise awareness concerning discrimination and has demanded reflection on the relationship between the law and sexuality, highlighting the need to adopt a human rights paradigm in this area. Another important trend in the development of LGBT rights has been their relationship to issues of access to health services. Countries with public health services, and especially those that intend to increase the population's access to such services, are faced with multiple demands relating to sexual rights (Parker and Corrêa 2003). This emphasises the need to provide health services that consider the specific situations of groups claiming sexual rights, such as travestis.

To conclude this inventory of trends in the development of LGBT rights in Latin America, one should not overlook a Latin American specificity when comparing the issue's evolution here and in Europe and North America. From the legal point of view, in Europe and North America the recognition of LGBT sexual rights began (and continues to 
develop) on the basis of demands invoking the right to privacy and the right to non-discrimination

(Heinze 1995). This involves so-called 'negative rights', i.e. demands for non-intrusion by either the state or third parties in individual choices and practices. For example, case law history in Europe and the USA has always emphasised privacy as the principal Constitutional premise for the affirmation of LGBT individual and group rights (Rios 2004).

The Latin American experience has revealed other alternatives. Demands for social rights have fuelled the discussion on LGBT rights. An example is the demand for social security rights and health plan entitlements, which has been the pioneering (and most successful) legal strategy for the recognition of LGBT rights in Brazil (Vianna 2004).

\section{Challenges to the development of LGBT rights}

Although recent, the development of LGBT rights in Latin America has met with several challenges, including: (1) the difficulty in developing a specific field related to sexual rights, not necessarily linked to the idea of reproductive rights; (2) the need to base sexual rights on a human rights paradigm rather than merely cultivating sexual health; (3) the conservative religious backlash against the recognition of LGBT sexual rights, and the difficulty in affirming a secular state; (4) the persistence of cultural realities that are incompatible with the development of LGBT sexual rights; and (5) socioeconomic conditions of poverty affecting huge population contingents in the region.

The history of international human rights instruments shows that sexual rights were not originally conceived as autonomous in relation to reproductive rights. On the contrary, they were seen as a kind of appendix to the idea of reproductive rights. In fact, historically speaking, the main underlying concern in the expression 'reproductive and sexual rights' has been to weigh against the injustice contained in gender relations and the denial of reproductive autonomy. There is no denying the importance of the struggle against reproductive and gender-based injustice. But, as LGBT rights make quite clear, the sphere of sexuality extends far beyond these limits (Parker and Corrêa 2003). It encompasses freedom of sexual expression and a range of issues affecting LGBT people. In addition, the affirmation of sexual rights even reaches sexual practices not associated with particular identities, with sadomasochism as a good example of this reality.
Another important challenge for the affirmation of LGBT sexual rights is the tendency towards a biomedical justification of such rights. To assess this challenge it is necessary to focus on the underlying tenets in the demand for such rights. While it is true that sexual health concerns are important for the achievement of sexual rights, it is equally true that the recognition of sexual rights stems from a broader perspective than merely preserving and cultivating health. Sexual rights in general, and especially LGBT sexual rights, are informed by a human rights perspective, one that may clash with narrower biomedical views. An arena where this conflict is particularly evident is the situation of travestis.

A critical aspect of this same challenge is the widespread resistance to the very idea of human rights in our Latin American countries. For a considerable share of our population, the very notion of human rights is perceived in a twisted and prejudiced way, as if human rights were devoted exclusively to protecting criminals. This mindset, the result of a long history of authoritarianism, permeates many institutions and groups both inside and outside the state, thus further hindering demands for LGBT rights based on human rights principles.

The emergence of fundamentalist religious movements poses another major challenge for the development of LGBT rights in Latin America. This trend is seen not only among many of the so-called neo-Pentecostal churches. Even in the heart of the Catholic Church, conservative currents in relation to sexual conduct have gained force. Together, these groups react to the empowerment of the LGBT movement by proposing, for example, legislation aimed at 'converting' homosexuals into heterosexuals, even making use of the public health system for this purpose. The difficulty in affirming the secular nature of the state in the young and immature Latin American democracies is a crucial obstacle, to the extent that our societies bear a historical experience of a strong, centuries-old institutional association between the Catholic Church and the civil state (Guesmez 2004).

Persistent representations of female inferiority and gender subordination, as expressed in such cultural formulations as machismo, pose another cultural challenge to the development of LGBT sexual rights 
in Latin America (see Parker and Corrêa 2003; Alpízar and Bernal 2004). We are dealing with a cultural context divorced from human rights principles, reaching such extreme examples as the assassination of gays and travestis and widespread sexual violence faced by women.

Finally, the precarious socioeconomic conditions affecting a major portion of the Latin American population pose a huge challenge for the enforcement of LGBT sexual rights. Poverty and destitution are real barriers against access to various benefits such as knowledge, information, and services related to sexuality. They limit the perception of risks related to unsafe sex. They maintain a barrier to formal schooling and have nefarious consequences for attempts to establish a social life free of prejudices.

\section{Conclusion}

In recent years the rights of LGBT persons have received greater institutional attention in Latin America. Legislative and legal gains have been made at various moments, some of which - such as the Ecuadorian Constitution and Brazilian antidiscrimination legislation - demonstrate significant changes in attitudes across the continent. It is, however, also the case that persistent factors challenging such rights still leave their affirmation and consolidation in jeopardy. If this situation is true for the countries in which these sexual rights have already reached some degree of recognition, it is all the more so in those countries where such rights have scarcely been achieved.

\section{Notes}

1 For further information on legal frameworks and experiences in these countries, see Cabal et al. (2001), Vianna (2004) and CLADEM (2003).

2 While in Europe and North America transvestism is generally associated with men who prefer
Within this framework, deepening and adequately understanding the situation of LGBT rights and how they can be protected and promoted at multiple levels is an indispensable task for legal authorities, professionals and civil society. By proceeding in this direction, a fruitful dialogue can be established between law-making and jurisprudence, public policies and initiatives by civil society, all in a virtuous circle. This dynamic can help overcome an exclusionary and stigmatising culture in relation to those whose identities as LGBT mark them as 'different', as well as resistance to freedom of sexual expression.

In effect, human rights-orientated legal practices can contribute not only to a more effective social response against discrimination, but also can help us overcome exclusionary mindsets and repressive legal categories, making a break with mechanisms of inequality and injustice in both the law and society as a whole (Rios 2004). Such kind of legal developments, affirming a human rights perspective, are a decisive step towards the justice and democracy in Latin America, especially for those groups that suffer widespread societal discrimination, such as LGBT people. The current situation in our countries, related to freedom of sexual expression, is an emblematic example of how rights, realities, societal and governmental efforts are pieces of a complex social, political and legal puzzle. In such a complex dynamic, everyone has to connect initiatives, expertise and efforts in order to build a society in which non-discrimination and freedom of sexual expression are not only legal and political principles, but also concrete alternatives for all.

sexual relations with the female sex, in Latin America transvestites (travestis) generally prefer same sex sexual relations. Many are engaged in sex work. See Campuzano in this IDS Bulletin. 


\section{References}

Alpízar, Lydia and Bernal, Marina (2004) 'Youth, Sexuality, and Human Rights: Some Reflections from Experience in Mexico', Health and Human Rights: Special Focus: Sexuality, Human Rights and Health 7.2: 217, Boston: Harvard School of Public Health

Cabal, Luisa, Roa, Mônica and Lemaitre, Julieta (eds) (2001) Cuerpo y Derecho - Legislación y Jurisprudencia en América Latina, Bogotá: Editorial Temis

Cáceres, Carlos, Pecheny, Mario and Terto Jr, Veriano (2002) Sida y Sexo Entre Hombres en América Latina: Vulnerabilidades, Fortalezas y Propuestas para la Acción, Peru: Universidad Peruana Cayetano Heredia

CLADEM (2003) Diagnóstico Sobre la Situación de los Derechos Sexuales y los Derechos Reproductivos, 1995-2002, Lima: Latin American and Caribbean Committee for Defence of Women's Rights (CLADEM)

Golin, Célio, Pocahy, Fernando and Rios, Roger (2003) A Justiça e dos Direitos de Gays e Lésbicas Jurisprudência Comentada, Porto Alegre: Editora Sulina
Guesmez, Ana (2004) Estado Laico, Sociedad Laica: un Debate Pendiente, Ciudadania Sexual En America Latina: Abriendo El Debate, Lima: Universidad Peruana Cayetano Heredia

Heinze, Eric (1995) Sexual Orientation: A Human Right, The Hague: Martinus Nijhoff

Leon, Magdalena (1999) Derechos Sexuales y Reproductivos. Avances Constitucionales y Perspectivas en Ecuador, Quito: Fundación Ecuatonana de Acción, Estudios y Participación Social (FEDAEPS)

Parker, Richard and Corrêa, Sonia (eds) (2003) Sexualidade e Política na América Latina, Rio de Janeiro: Associação Brasileira Interdisciplinar de AIDS (ABIA)

Rios, Roger Raupp (2004) 'Apuntes Para un Derecho Democrático de la Sexualidad', Ciudadania Sexual En America Latina: Abriendo El Debate, Lima: Universidad Peruana Cayetano Heredia

Vianna, Adriana (2004) Direitos e Políticas Sexuais no Brasil: Mapeamento e Diagnóstico, Rio de Janeiro: Centro de Pesquisas e Desenvolvimento para a Segurança das Communicações (CEPESC) 